\title{
Developing a live cell assay for the centriole-cilium transition in flies
}

\author{
H Roque*, J Raff \\ From Cilia 2014 - Second International Conference \\ Paris, France. 18-21 November 2014
}

Cilia are essential organelles for organism development and have been linked with several human diseases, so called ciliopathies. A cilium is formed from a mother centriole that extends into a separate membrane compartment at the cell surface. Despite the large number of proteins associated with cilia formation/development the interplay of proteins that allow a centriole to form a cilium are largely unknown. Using the well characterised Drosophila sensory organ precursor (SOP) cells as a model, we propose to dissect the molecular pathway of cilia formation with live cell imaging and electron microscopy. SOPs divide in a stereotypical manner to produce four cells, only one of which will form a cilium. We have started by imaging centriole dynamics during the SOP divisions to determine how centrioles behave prior to differentiation and cilium formation. These very early studies reveal that centrioles are highly motile, but are tightly apically constricted in the SOP cells and most of their progeny. Further advances in the methodology will be discussed.

Published: 13 July 2015

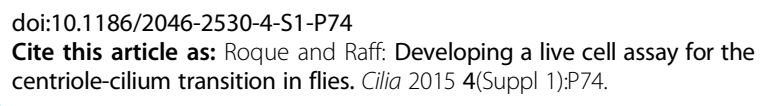

doi:10.1186/2046-2530-4-S1-P74

Cite this article as: Roque and Raff: Developing a live cell assay for the centriole-cilium transition in flies. Cilia 2015 4(Suppl 1):P74.

Sir William Dunn School of Pathology, University of Oxford, Oxford, UK

(C) 2015 Roque and Raff. This is an Open Access article distributed under the terms of the Creative Commons Attribution License (http://creativecommons.org/licenses/by/4.0), which permits unrestricted use, distribution, and reproduction in any medium, provided the original work is properly cited. The Creative Commons Public Domain Dedication waiver (http://creativecommons.org/ publicdomain/zero/1.0/) applies to the data made available in this article, unless otherwise stated.

Submit your next manuscript to BioMed Central and take full advantage of:

- Convenient online submission

- Thorough peer review

- No space constraints or color figure charges

- Immediate publication on acceptance

- Inclusion in PubMed, CAS, Scopus and Google Scholar

- Research which is freely available for redistribution

\section{Biomed Central}

